\title{
NFATC3 Gene
}

National Cancer Institute

\section{Source}

National Cancer Institute. NFATC3 Gene. NCI Thesaurus. Code C93148.

This gene plays a role in T-cell-mediated transcription. 